\title{
Combination of topical agents and oxybutynin as a therapeutic modality for patients with both osmidrosis and hyperhidrosis
}

\author{
Andrea Yasbek Monteiro Varella ${ }^{1}$, Juliana Maria Fukuda ${ }^{1 *} \odot$, Marcelo Passos Teivelis $^{1}$, Lucas Lembrança Pinheiro ${ }^{1}$, \\ Cynthia de Almeida Mendes ${ }^{1}$, Paulo Kauffman ${ }^{1,2}$, José Ribas Milanez de Campos ${ }^{3,4}$, Nelson Wolosker ${ }^{1,2}$ \\ ${ }^{1}$ Division of Vascular and Endovascular Surgery, Hospital Israelita Albert Einstein, São Paulo, SP, Brazil \\ ${ }^{2}$ Division of Vascular and Endovascular Surgery, Hospital das Clínicas da Faculdade de Medicina da Universidade de São Paulo (HC-FMUSP), São Paulo, SP, Brazil \\ ${ }^{3}$ Division of Thoracic Surgery, Hospital Israelita Albert Einstein, São Paulo, SP, Brazil \\ ${ }^{4}$ Division of Thoracic Surgery, HC-FMUSP, São Paulo, SP, Brazil
}

Study conducted at Hospital Israelita

Albert Einstein, and at Hospital das Clínicas da Faculdade de Medicina da Universidade de São Paulo (HC-FMUSP), São Paulo, SP, Brazil

Article received: $7 / 19 / 2017$ Accepted for publication: 9/9/2017

*Correspondence:

Address: Av. Albert Einstein, 627 bloco A1, $4^{\circ}$ andar, sala 423 , Morumbi

São Paulo, SP - Brasil Postal code: 05652-000 ju_mfukuda@yahoo.com

http://dx.doi.org/10.1590/1806-9282.64.02.127

\section{SUMmARY}

Introduction: The association of osmidrosis and hyperhidrosis often causes emotional and social problems that may impair the patients' quality of life. The purpose of our study was to analyze the therapeutic results of oxybutynin and topical agents in 89 patients with both osmidrosis and hyperhidrosis.

Method: We conducted an observational study at two specialized centers of hyperhidrosis between April 2007 and August 2013. Eighty-nine (89) patients with both osmidrosis and hyperhidrosis were treated with oxybutynin and topical agents. Patients were evaluated before treatment and at 3 and 6 weeks after treatment started, by using the Quality of Life Questionnaire and the Sweating Evolution Scale.

Results: Before treatment, $98 \%$ of the patients presented with poor or very poor quality of life. After six weeks of treatment, $70 \%$ stated their quality of life as being slightly better or much better $(p<0.001)$ and nearly $70 \%$ of the patients experienced a moderate or great improvement in sweating and malodor. Improvement in osmidrosis was significantly greater when the axillary region was the first most disturbing site of hyperhidrosis.

Conclusion: There was a significant improvement in quality of life and a reduction in sweating and malodor after six weeks of treatment with topical agents and oxybutynin in patients with both hyperhidrosis and osmidrosis. Therefore, clinical treatment should be considered before invasive techniques.

Keywords: Hyperhidrosis. Apocrine Glands. Muscarinic Antagonists. Sweat Gland Diseases.

\section{INTRODUCTION}

Osmidrosis $(\mathrm{OH})$ is a disease caused by excessive secretion of the apocrine glands, resulting in malodor, mainly in the axillary and genital areas. It often causes emotional and social problems that may impair the patients' quality of life (QoL). Some patients with $\mathrm{OH}$ also have hyperhidrosis $(\mathrm{HH})$, which is characterized by the overproduction of sweat by eccrine glands covering the body's surface, predominantly in the palmar, plantar, axillary and craniofacial regions. When $\mathrm{OH}$ and $\mathrm{HH}$ occur together, the problem becomes even more distressing for patients. ${ }^{1}$

In our institution, many patients present with both $\mathrm{HH}$ and $\mathrm{OH}$. In such cases, treatment includes oxybutynin and topical agents. Oxybutynin is an anticholinergic drug that has been shown to decrease sweating and improve QoL with few side effects in more than $70 \%$ of the patients. ${ }^{2-4}$ If this treatment fails, sympathectomy may be the first surgical choice for palmar $\mathrm{HH}$ and can be considered as a surgical alternative for axillary and facial $\mathrm{HH}$ because it is a definitive therapeutic option. ${ }^{5,6}$ The topical agents used in our service are Sastid ${ }^{\circledR}$ (Stiefel, a GSK company, Middlesex, United Kingdom), which is a soap containing salicylic acid and sulfur that has fungicidal and keratolytic action, and Clinage ${ }^{\circledR}($ Stiefel, a GSK company, Middlesex, United Kingdom), which is a clindamycin $10 \mathrm{mg} / \mathrm{g}(1 \%)$ gel. 
To the best of our knowledge, no study has demonstrated the therapeutic results of the combination of oxybutynin and topical agents in patients with both $\mathrm{OH}$ and $\mathrm{HH}$. This study aimed to analyze the therapeutic results of oxybutynin and topical agents in 89 patients with both $\mathrm{OH}$ and $\mathrm{HH}$.

\section{Method}

This was a retrospective study with a review of the patients' data at two specialized centers of $\mathrm{HH}$ (Hospital Israelita Albert Einstein and Hospital das Clínicas da Faculdade de Medicina da Universidade de São Paulo) between April 2007 and August 2013. Our study was conducted in accordance with the standards of the Ethics Committee for Analysis of Research Projects on Human Experimentation (Approval numbers at Plataforma Brasil: CAAE01582112.6.1001.0071 and CAAE01582112.2.3001.0068); all subjects gave informed consent. A total of 89 patients with both $\mathrm{OH}$ and $\mathrm{HH}$ in the axillary region and in other sites were treated with oxybutynin and topical agents. Follow-up was conducted 3 and 6 weeks after treatment started. Patients with compensatory $\mathrm{HH}$ were not included.

The group comprised 74 women (83\%) and 15 men (17\%), aged 5 to 57 years, with a median age of 27 years. The patients' body mass index (BMI) ranged from 15.7 to $33.2 \mathrm{~kg} / \mathrm{m}^{2}$, with a median of $23 \mathrm{~kg} / \mathrm{m}^{2}$.

At the first visit, oxybutynin and both topical agents $\left(\right.$ Sastid $^{\circledR}$ and Clinagel ${ }^{\circledR}$ ) were introduced. The soap and the gel were used once a day, daily.

Oxybutynin was prescribed for six weeks, in progressively increasing doses throughout treatment. At the first visit, patients were given $2.5 \mathrm{mg}$ of oxybutynin to be taken once a day in the evening, for one week; they were then instructed to increase the dose to $2.5 \mathrm{mg}$ twice a day from the $8^{\text {th }}$ to the $21^{\text {st }}$ day, after which a second visit was scheduled (three weeks of treatment). After this period of time, the dose was increased to $5 \mathrm{mg}$ twice a day from the $22^{\text {nd }}$ to the $42^{\text {nd }}$ day, after which a third visit was scheduled (six weeks of treatment).

The patients were evaluated three times: at the first visit (before medications) and after the $3^{\text {rd }}$ and $6^{\text {th }}$ weeks, using the QoL questionnaire ${ }^{7}$ and the Sweating Evolution Scale.

Patients answered the QoL questionnaire at the first visit and after six weeks of treatment. The QoL questionnaire consists of 20 specific questions about $\mathrm{HH} / \mathrm{OH}$, divided in five domains. Each domain or group contains five degrees of answers and the patient indicated only one, with scores ranging from 20 to 100 . According to the scoring system, a higher score reflects a poorer QoL. QoL before treatment was considered very poor if the sum of points was greater than 83 ; poor if the sum was from 68 to 83 ; good if the sum was 52 to 67 ; very good if the sum was 36 to 51; and excellent if the sum was 20 to 35 .

At the $6^{\text {th }}$ week of treatment, QoL was classified as much worse when the total score was greater than 83; slightly worse when the total score was between 68 and 83; the same when the total score was between 52 and 67; slightly better when the total score was between 36 and 51; and much better when the total score was between 20 and 35 .

The Sweating Evolution Scale is based on the patient's subjective perception of improvement in $\mathrm{HH} / \mathrm{OH}$ after treatment. It was used at the second and third visits for all study participants. The scale ranges from 0 to 10 , with 0 representing no improvement and 10 representing absence of $\mathrm{HH}$. If the score was between 1 and 4, the improvement was considered slight; if the score was between 5 and 7, the improvement was considered moderate; and if the score was between 8 and 10, the improvement was considered great.

We analyzed the number and sites with HH symptoms in addition to axillary $\mathrm{OH}$ ( $\mathrm{HH}$ sites associated with $\mathrm{OH})$; the distribution of patients according to site of complaint; the association between $\mathrm{OH}$ and $\mathrm{HH}$ (sites of $\mathrm{HH}$ and the most disturbing complaints of the patients); the number of patients who mentioned $\mathrm{OH}$ as the first, second, third, or fourth complaint; the impact of $\mathrm{OH}$ on $\mathrm{QoL}$ before treatment; the effect of treatment on QoL; and the improvement in malodor and sweating after treatment.

The numerical variables were expressed by using mean and standard deviation, with normality being verified with the Shapiro-Wilk test. When normality could not be assumed, the variables were described as median and interquartile range. Categorical variables were described by using absolute and relative frequencies.

The Wilcoxon rank-sum test was used to analyze the self-reported improvement in malodor and sweating over the consecutive medical visits and to compare the therapeutic results between $\mathrm{OH}$ and $\mathrm{HH}$. The same test was used to compare the impairment in QoL throughout the treatment. McNemar's test was used to compare categorical levels of malodor improvement.

The results were presented using $\mathrm{p}$ values. The significance level for all tests was $\mathrm{p}=0.05$.

\section{Results}

All the patients with both $\mathrm{OH}$ and $\mathrm{HH}$ had axillary $\mathrm{HH}$ associated, wherein $80 \%$ of the patients reported axillary $\mathrm{HH}$ as the first most disturbing complaint. OH was never the first most disturbing complaint. In more than half of the patients (51 out of 89 ), $\mathrm{OH}$ was reported as the 
second most disturbing complaint. Figure 1 shows the most disturbing sites of complaint by patients.

The number of body sites affected by $\mathrm{HH}$ and their locations are presented in Table 1. Most patients (86\%) had $\mathrm{HH}$ in one, two or three sites in addition to $\mathrm{OH}$. The other $14 \%$ of patients had $\mathrm{HH}$ in four or more sites.

The sites of $\mathrm{HH}$ that were associated with axillary malodor are shown in Table 1. Palmar or plantar $\mathrm{HH}$ were present in almost half of the patients.

The effect of $\mathrm{OH}$ and $\mathrm{HH}$ on QoL before and after six weeks of treatment as well as the evolution of $\mathrm{OH}$ and $\mathrm{HH}$ (considering $\mathrm{OH}$ and the most disturbing site of $\mathrm{HH}$ in each patient) after 3 and 6 weeks according to the Sweating Evolution Scale are presented in Table 2.

Before treatment, almost all patients (98\%) ranked their QoL as poor or very poor. After six weeks of treatment, the improvement in QoL was substantial and most patients (70\%) considered their QoL as slightly or much better, with a statistically significant difference $(p<0.001)$.

After three weeks of treatment, we observed an improvement of $31 \%$ in symptoms of $\mathrm{OH}$ and a $41 \%$ improvement in symptoms of $\mathrm{HH}$, with no statistical difference. After six weeks of treatment, nearly $70 \%$ of the patients experienced moderate to great improvement in symptoms of both $\mathrm{OH}$ and $\mathrm{HH}$.

Considering only $\mathrm{OH}$, we observed that patients taking subdoses of oxybutynin (results of three weeks) showed less improvement. However, when the full dose of oxybu- tynin was taken (results of six weeks), patients experienced a significant improvement. The same occurred with $\mathrm{HH}$ symptoms, showing that clinical efficacy depends on the correct oxybutynin dose.

We also observed that the improvement in OH symptoms was significantly greater when the axillary region was the first most disturbing site of $\mathrm{HH}$ if compared to the results in patients with plantar and palmar areas as the first most disturbing sites of $\mathrm{HH}$.

\section{Discussion}

$\mathrm{OH}$ is a disease that disrupts patients' social and professional lives. Its prevalence is about $4.5 \%$ in Han Chinese. ${ }^{8}$ The exact etiology of $\mathrm{OH}$ has not been elucidated yet, ${ }^{9}$ but it is known to be a familial hereditary disease, with the involvement of genetic mechanisms and the influence of androgens on the secretion of the apocrine glands., ${ }^{8,10-12}$ The influence of sex hormones on the pathophysiology of $\mathrm{OH}$ justifies its larger frequency during puberty. ${ }^{8}$

Similar to other authors, we observed a higher frequency of $\mathrm{OH}$ among female patients, although the reason is unknown. ${ }^{13,14}$ Nokita et al. ${ }^{15}$ suggested that cultural, psychological, hormonal and physiologic factors may make women more sensitive to malodor.

Surgical excision of the subcutaneous tissue and/or the overlying skin, which entails a complete excision of the apocrine and eccrine glands, ${ }^{16}$ can be performed to

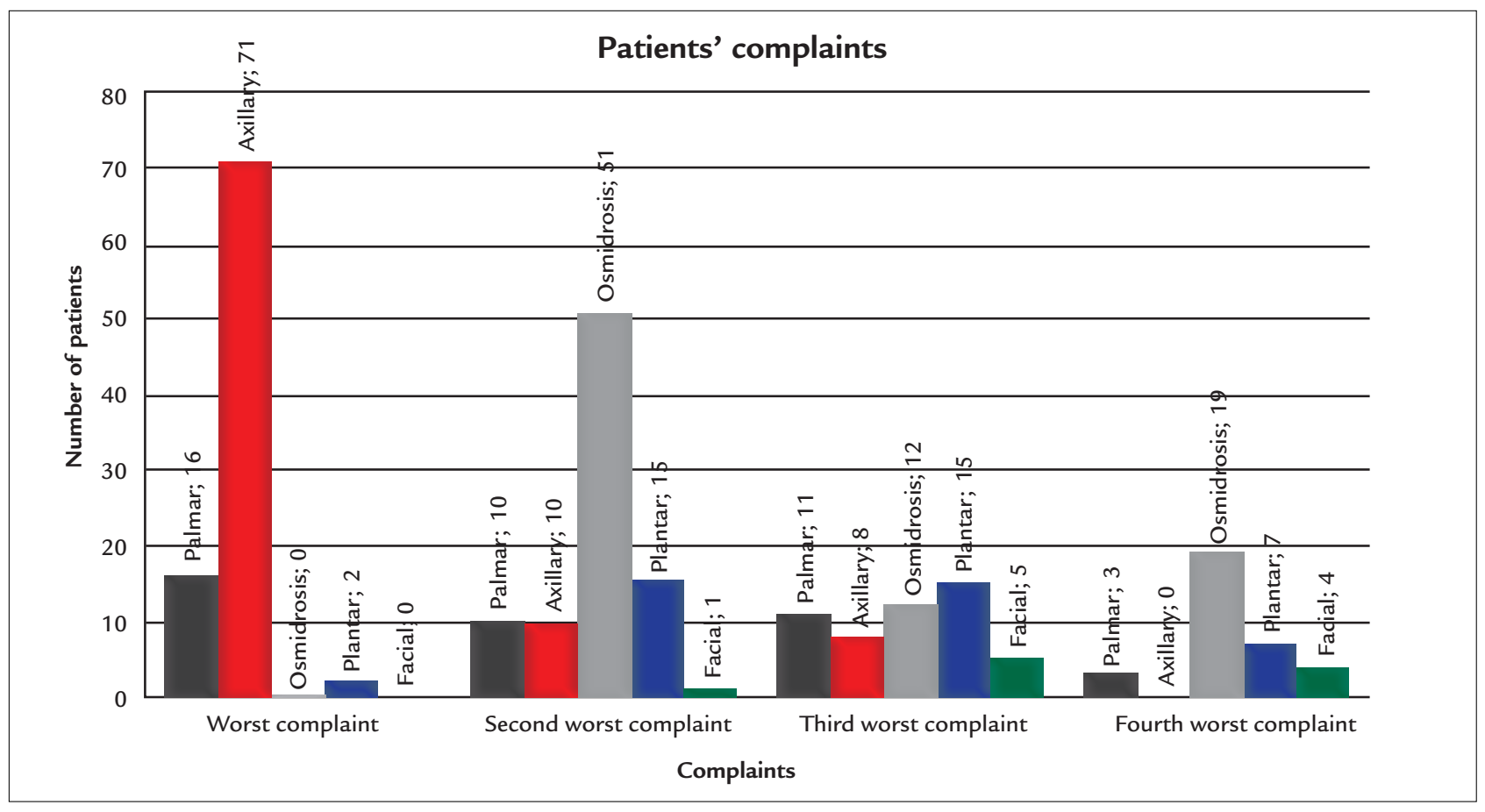

FIGURE 1 Distribution of patients according to sites of complaint. 
TABLE 1 Number and locations of hyperhidrosis sites in addition to axillary osmidrosis. Hyperhidrosis sites associated with osmidrosis.

Number and locations of hyperhidrosis sites

1 site

Axillary

2 sites

Axillary and Palmar

Axillary and Plantar

Axillary and Legs

Axillary and Back

Axillary and Facial

3 sites

Axillary and Palmar and Plantar

Axillary and Palmar and Abdominal

Axillary and Palmar and Facial

Axillary and Palmar and Scalp

Axillary and Palmar and Legs

Axillary and Thorax and Legs

Axillary and Thorax and Back

Axillary and Facial and Back

Axillary and Plantar and Inguinal

4 sites

Axillary and Palmar and Plantar and Facial

Axillary and Palmar and Plantar and Back

Axillary and Palmar and Plantar and Legs

Axillary and Abdominal and Back and Breast

Axillary and Abdominal and Back and Thorax

5 sites

Axillary and Plantar and Abdominal and Legs and Inguinal

Axillary and Palmar and Plantar and Back and Backside

6 sites

Axillary and Back and Breast and Plantar and Facial and Backside

Axillary and Back and Breast and Plantar and Facial and Palmar

Total

\begin{tabular}{lll}
\hline & $\begin{array}{l}\text { Axillary hyperhidrosis } \\
\mathbf{n = 8 9}(\mathbf{1 0 0 \% )}\end{array}$ & $\begin{array}{l}\text { Facial hyperhidrosis } \\
\mathbf{n = 1 1}(\mathbf{1 2 \% )}\end{array}$ \\
\hline Male & $15(17 \%)$ & $6(55 \%)$ \\
\hline Female & $74(83 \%)$ & $5(45 \%)$ \\
\hline
\end{tabular}

89

Palmar hyperhidrosis Plantar hyperhidrosis $n=40(45 \%)$

$8(20 \%)$

$32(80 \%)$
$\%$

33

33

22

9.5

9.5

1

1

1

31

22

22

1

1

1

$1+1$

1

$1+1$

9

5

1

1

1

1

1

1

2 2

1

1

100

Other sites of hyperhidrosis $n=18(20 \%)$ $2(11 \%)$ $16(89 \%)$

TABLE 2 Quality of life before treatment and six weeks later. Evolution of osmidrosis and hyperhidrosis after 3 and 6 weeks of treatment.

\begin{tabular}{|c|c|c|c|c|c|c|c|}
\hline QoL & \multicolumn{3}{|c|}{ Before treatment $\mathrm{n}(\%)$} & QoL & \multicolumn{3}{|c|}{6 weeks later n (\%) } \\
\hline Very poor & $50(56 \%)$ & & & Much worse & 0 & & \\
\hline Poor & $37(42 \%)$ & & & Slightly worse & 0 & & \\
\hline Good & $2(2 \%)$ & & & The same & $27(30 \%)$ & & \\
\hline Very good & 0 & & & Slightly better & $59(67 \%)$ & & \\
\hline Excellent & 0 & & & Much better & $3(3 \%)$ & & \\
\hline Improvement in $\mathrm{OH}$ & 3 weeks n (\%) & 6 weeks n (\%) & $\mathbf{p}^{\#}$ & Improvement in $\mathrm{HH}$ & 3 weeks n (\%) & 6 weeks n (\%) & $\mathbf{p}^{\#}$ \\
\hline Slight & $49(69 \%)$ & $31(35 \%)$ & $<0.001$ & Slight & $36(59 \%)$ & $27(30 \%)$ & 0.004 \\
\hline Moderate & $14(20 \%)$ & $27(30 \%)$ & $<0.001$ & Moderate & $17(28 \%)$ & $39(44 \%)$ & 0.004 \\
\hline Great & $8(11 \%)$ & $31(35 \%)$ & $<0.001$ & Great & $8(13 \%)$ & $23(26 \%)$ & 0.004 \\
\hline
\end{tabular}

QoL: quality of life; $\mathrm{OH}$ : osmidrosis; $\mathrm{HH}$ : hyperhidrosis.

"McNemar's test. 
reduce malodor and sweating. Minimally invasive procedures ${ }^{17-20}$ such as liposuction, laser therapy, subdermal shaving, microwave-based device and ultrasonic surgical aspiration are also used to reduce malodor and sweating caused by the excessive secretion of these glands.

However, recurrence of malodor is more frequent with minimally invasive procedures. Complete excision of the glands, although having a lower recurrence rate, leads to significant scarring, longer periods of bandaging and a higher risk of complications. ${ }^{10,17}$

Nonsurgical methods for the treatment of $\mathrm{HH}$ and $\mathrm{OH}$ include topical antiperspirants, iontophoresis, Botox injection and the use of anticholinergic drugs. ${ }^{9,21,22}$ Unless there are formal contraindications such as closed-angle glaucoma, intestinal obstruction and severe dermatologic complaints, we empirically treat our patients with both $\mathrm{HH}$ and $\mathrm{OH}$ with a soap containing salicylic acid and sulfur $\left(\right.$ SASTID $\left.^{\circledR}\right)$ which has a fungicidal and keratolytic action, associated to a gel containing topical antibiotic (CLINA$\mathrm{GEL}^{\circledR}$ ), combined with oxybutynin. The oxybutynin is an anticholinergic drug used for $\mathrm{HH}$ with a high efficacy rate and scientific evidence to support its use. ${ }^{3,23}$

All the patients with $\mathrm{OH}$ had an association with axillary HH. In Western countries, people tend to ask for treatment of $\mathrm{HH}$ rather than of $\mathrm{OH}$. In Asian countries, patients are more concerned about controlling $\mathrm{OH} .{ }^{24}$ This is the reason why most of the studies on $\mathrm{OH}$ are from Asian countries.

In our study, all the patients sought medical care for $\mathrm{HH}$ rather than for $\mathrm{OH}$. The fact that we are a referral center for patients with $\mathrm{HH}$ may also account for why all the patients in our study had HH.

The axillary region was the only $\mathrm{HH}$ site in patients presenting with malodor, while excessive sweat was present in different sites of the body. $\mathrm{HH}$ was more frequent in the axillary region, a fact noted by all the patients. The palmar region was the second most affected site of $\mathrm{HH}(45 \%)$ followed by the soles (44\%); the other sites of $\mathrm{HH}$ were present in $20 \%$ of the patients. These rates are similar to those of the population affected by $\mathrm{HH} .{ }^{25}$ The face was affected by excessive sweat in $12 \%$ of the patients in our study, probably because our sample had a median age of 27 years; the symptoms of facial $\mathrm{HH}$ commonly start in adulthood and patients tend to seek treatment for this condition in their $40 \mathrm{~s}^{26}$

To the best of our knowledge, no previous study has evaluated QoL in patients with both $\mathrm{HH}$ and OH. Most studies analyze only the improvement in symptoms and the presence of complications related to the therapy. In our study, however, we evaluated patients' QoL before treatment and six weeks after treatment started. Seventy percent (70\%) reported that their QoL had improved slightly or was much better after six weeks of treatment. Before treatment, none of the patients considered their QoL very good or excellent; only 2\% reported it as good.

The treatment of both $\mathrm{OH}$ and $\mathrm{HH}$ with the combination of topical agents and subdoses of oxybutynin (clinically insufficient dose) led to a significantly lower improvement when compared to patients using topical agents and the full dose of oxybutynin $(10 \mathrm{mg})$. The full dose of oxybutynin was effective (moderate or great improvement) in reducing malodor in $65 \%$ of the patients; $70 \%$ experienced a reduction in sweating and $70 \%$ reported that their QoL was slightly or much better than before treatment.

We have not found any study that evaluated the results in patients with both $\mathrm{HH}$ and $\mathrm{OH}$ who had been treated with noninvasive methods. Comparing our results with other publications, we achieved similar results to those of Seo et al., ${ }^{27}$ who showed $72.1 \%$ of good to excellent results in patients with axillary $\mathrm{OH}$ after liposuction with curettage. The same author reported that 8 out of 43 patients (19\%) had complications such as ecchymosis, focal skin necrosis, induration, hematoma and seroma. Lee et al. ${ }^{28}$ reported that excellent results were achieved in $76 \%$ of the patients and $22 \%$ experienced good results after tumescent liposuction with dermal curettage for treatment of axillary $\mathrm{HH}$ and $\mathrm{OH}$. Other surgical treatments showed higher rates of satisfaction among patients (80.6\% to $98.9 \%$ ), but these patients experienced a higher number of complications (10.7\% to $45.2 \%$ ). ${ }^{29-31}$

A weakness of our study is the assessment of the relative influence of topical agents on the amelioration of $\mathrm{OH}$. Would the results be different if patients had received only oxybutynin or just topical treatment? Only a prospective and randomized study (with a topical agent as placebo) could definitely provide an answer to this question; such a trial is under consideration in our centers. Nevertheless, because all of our patients presented with $\mathrm{HH}$ in at least one site in addition to $\mathrm{OH}$, oral and topical treatment were beneficial to the majority of the patients.

Although the treatment of $\mathrm{OH}$ with topical agents and oxybutynin is not the solution for every patient, it is effective for most of them. Therefore, they should be used as the first alternative at the beginning of the treatment for patients with $\mathrm{OH}$ associated with $\mathrm{HH}$ before indicating other therapeutic modalities.

\section{Conclusion}

We observed a significant improvement in QoL and a reduction in sweating and malodor after six weeks of treatment with oxybutynin and topical agents in patients with both $\mathrm{HH}$ and $\mathrm{OH}$. The combination of oxybutynin and topical agents is a good alternative for patients with both $\mathrm{HH}$ and $\mathrm{OH}$. 


\section{Resumo}

Uso combinado de agentes tópicos e oxibutinina para tratamento de pacientes com osmidrose e hiper-hidrose

Introdução: A associação entre osmidrose e hiper-hidrose com frequência causa problemas emocionais e sociais que podem deteriorar a qualidade de vida dos pacientes. O objetivo deste estudo foi analisar os resultados terapêuticos do uso de oxibutinina associada a agentes tópicos em 89 pacientes com osmidrose e hiper-hidrose.

Método: Nós conduzimos um estudo observacional em dois centros especializados em hiper-hidrose entre abril de 2007 e agosto de 2013. Oitenta e nove (89) pacientes com osmidrose associada a hiper-hidrose foram tratados com oxibutinina e agentes tópicos. Os pacientes foram avaliados antes do tratamento e após 3 e 6 semanas do início do tratamento, por meio do Questionário de Qualidade de Vida e da Escala de Evolução da Sudorese.

Resultados: Antes do tratamento, 98\% dos pacientes apresentavam qualidade de vida ruim ou muito ruim. Após seis semanas de tratamento, $70 \%$ classificou sua qualidade de vida como sendo pouco ou muito melhor $(\mathrm{p}<0.001)$ e aproximadamente $70 \%$ dos pacientes relataram melhora moderada ou grande de sudorese e odor. Houve melhora significativamente maior da osmidrose quando a região axilar era o sítio em que a hiper-hidrose mais incomodava.

Conclusão: Houve melhora significativa da qualidade de vida e uma redução da sudorese e do odor após seis semanas de tratamento com agentes tópicos e oxibutinina em pacientes com hiper-hidrose associada a osmidrose. Dessa maneira, a terapia clínica deve ser considerada antes de técnicas invasivas.

Palavras-chave: Hiperidrose. Glândulas Apócrinas. Antagonistas Muscarínicos. Doenças das Glândulas Sudoríparas.

\section{References}

1. Hamm H, Naumann MK, Kowalski JW, Kütt S, Kozma C, Teale C. Primary focal hyperhidrosis: disease characteristics and functional impairment. Dermatology. 2006; 212(4):343-53.

2. Wolosker N, Schvartsman C, Krutman M, Campbell TP, Kauffman P, Campos JR, et al. Efficacy and quality of life outcomes of oxybutynin for treating palmar hyperhidrosis in children younger than 14 years old. Pediatr Dermatol. 2014; 31(1):48-53.

3. Wolosker N, Campos JR, Kauffman P, Neves S, Munia MA, Jatene FB, et al. The use of oxybutynin for treating axillary hyperhidrosis. Ann Vasc Surg. 2011; 25(8):1057-62.

4. Wolosker N, Campos JR, Kauffman P, Yazbek G, Neves S, Puech-Leão P. Use of oxybutynin for treating plantar hyperhidrosis. Int J Dermatol. 2013; 52(5):620-3.

5. Wolosker N, Campos JR, Kauffman P, Oliveira LA, Munia MA, Jatene FB. Evaluation of quality of life over time among 453 patients with hyperhi- drosis submitted to endoscopic thoracic sympathectomy. J Vasc Surg. 2012; 55(1):154-6.

6. Campos JRM, Kauffman P, Wolosker N, Munia MA, Werebe EC, Andrade Filho LO, et al. Axillary hyperhidrosis: T3/T4 versus T4 thoracic sympathectomy in a series of 276 cases. J Laparoendosc Adv Surg Tech A. 2006; 16(6):598-603.

7. Amir M, Arish A, Weinstein Y, Pfeffer M, Levy Y. Impairment in quality of life among patients seeking surgery for hyperhidrosis (excessive sweating): preliminary results. Isr J Psychiatry Relat Sci. 2000; 37(1):25-31.

8. Chen H, Yang G, Li Y, Li X, Du J. Expression of apolipoprotein D and androgen receptor in axillary osmidrosis and its molecular mechanism. Int J Clin Exp Med. 2013; 6(7):497-503.

9. Mao GY, Yang SL, Zheng JH. Etiology and management of axillary bromidrosis: a brief review. Int J Dermatol. 2008; 47(10):1063-8.

10. Park YJ, Shin MS. What is the best method for treating osmidrosis? Ann Plast Surg. 2001; 47(3):303-9.

11. Nakano M, Miwa N, Hirano A, Yoshiura K, Niikawa N. A strong association of axillary osmidrosis with the wet earwax type determined by genotyping of the ABCC11 gene. BMC Genet. 2009; 10:42.

12. Sun Y, Long J, Wang Y. [Correlation between ABCC11 gene single nucleotide polymorphism and the incidence of axillary osmidrosis in Chinese Han population]. Zhong Nan Da Xue Xue Bao Yi Xue Ban. 2013; 38(11):1141-5.

13. Morioka D, Ohkubo F, Amikura Y. Clinical features of axillary osmidrosis: a retrospective chart review of 723 Japanese patients. J Dermatol. 2013; 40(5):384-8.

14. Lee JC, Kuo HW, Chen CH, Juan WH, Hong HS, Yang CH. Treatment for axillary osmidrosis with suction-assisted cartilage shaver. Br J Plast Surg. 2005; 58(2):223-7.

15. Nokita M. [Osmidrosis axillae]. Kangogaku Zasshi. 1970; 34(8):84-90.

16. Liu Q, Zhou Q, Song Y, Yang S, Zheng J, Ding Z. Surgical subcision as a cost-effective and minimally invasive treatment for axillary osmidrosis. J Cosmet Dermatol. 2010; 9(1)44-9.

17. Lee HC, Chen CC, Lee WY, Chuang HU, Kao MC. Axillary hyperhidrosis and osmidrosis treated by ultrasonic surgical aspiration compared with transthoracic endoscopic sympathectomy. Surg Neurol. 2008; 70(Suppl 1):S1:64-8.

18. Kim HG. A new osmidrosis procedure, the scrape and suction technique: review of 4,322 patients. Aesthetic Plast Surg. 2014; 38(2):282-7.

19. Jung SK, Jang HW, Kim HJ, Lee SG, Lee KG, Kim SY, et al. A prospective, long-term follow-up study of 1,444 nm Nd:YAG Laser: a new modality for treating axillary bromhidrosis. Ann Dermatol. 2014; 26(2):184-8.

20. Shim HS, Min SK, Lim JS, Han KT, Kim MC. Minimal subdermal shaving by means of sclerotherapy using absolute ethanol: a new method for the treatment of axillary osmidrosis. Arch Plast Surg. 2013; 40(4):440-4.

21. Li WW, Liu ZF, Cui YN, Zeng A. [Comparison study on the efficacy of three methods for the treatment of osmidrosis]. Zhonghua Zheng Xing Wai Ke Za Zhi. 2010; 26(5):348-50.

22. Guillet G, Zampetti A, Aballain-Colloc ML. Correlation between bacterial population and axillary and plantar bromidrosis: study of 30 patients. Eur J Dermatol. 2000; 10(1):41-2.

23. Wolosker N, Campos JR, Kauffman P, Puech-Leão P. A randomized placebocontrolled trial of oxybutynin for the initial treatment of palmar and axillary hyperhidrosis. J Vasc Surg. 2012; 55(6):1696-700.

24. Qian JG, Wang XJ. Effectiveness and complications of subdermal excision of apocrine glands in 206 cases with axillary osmidrosis. J Plast Reconstr Aesthet Surg. 2010; 63(6):1003-7.

25. Lear W, Kessler E, Solish N, Glaser DA. An epidemiological study of hyperhidrosis. Dermatol Surg. 2007; 33(1 Spec No.):S69-75.

26. Wolosker N, Campos JR, Kauffman P, Munia MA, Neves S, Jatene FB, et al. The use of oxybutynin for treating facial hyperhidrosis. An Bras Dermatol. 2011; 86(3):451-6.

27. Seo SH, Jang BS, Oh CK, Kwon KS, Kim MB. Tumescent superficial liposuction with curettage for treatment of axillary bromhidrosis. J Eur Acad Dermatol Venereol. 2008; 22(1):30-5.

28. Lee D, Cho SH, Kim YC, Park JH, Lee SS, Park SW. Tumescent liposuction with dermal curettage for treatment of axillary osmidrosis and hyperhidrosis. Dermatol Surg. 2006; 32(4):505-11.

29. Yoshikata R, Yanai A, Takei T, Shionome H. Surgical treatment of axillary osmidrosis. Br J Plast Surg. 1990; 43(4):483-5.

30. Endo T, Nakayama Y. Surgical treatment of axillary osmidrosis. Ann Plast Surg. 1993; 30(2):136-9.

31. Tung TC, Wei FC. Excision of subcutaneous tissue for the treatment of axillary osmidrosis. Br J Plast Surg. 1997; 50(1):61-6. 